\title{
THE EFFECTS OF DIFFERENT GIBBERELLIC ACID DOSES AND APPLICATION TIMES ON CHICKPEA PLANTS
}

\author{
ERGIN, N. ${ }^{1}-$ KAYAN, N..$^{2 *}$ \\ ${ }^{I}$ Department of Field Crops, Faculty of Agriculture and Naturel Sciences, Seyh Edebali \\ University, 11100 Bilecik, Turkey \\ (e-mail: nurgul.ergin@bilecik.edu.tr; phone: +90-228-214-1796; fax: +90-228-214-1027) \\ ${ }^{2}$ Department of Field Crops, Faculty of Agriculture, Eskisehir Osmangazi University, 26480 \\ Eskisehir, Turkey \\ *Corresponding author \\ e-mail: nkayan@ogu.edu.tr; phone: +90-222-324-2991; fax: +90-222-324-2990 \\ (Received $15^{\text {th }}$ Feb 2021; accepted $14^{\text {th }}$ May 2021)
}

\begin{abstract}
Plant hormones, specialized chemical substances produced by plants, are the main internal factors controlling growth and development. Gibberellic acid is an important growth promoter in plants, and the worldwide demand for it is steadily increasing. The purpose of this study was to identify the effects of different gibberellic acid doses and application times on the yield and agronomic characteristics of chickpea (Cicer arietinum L.). These researches were conducted at Applying Research Area, Faculty of Agriculture, University of Eskisehir Osmangazi in 2013 and 2014. The experimental design was split plot with four replicates. Different growth stages (2-3 leaves stage, pre-flowering stage, pod pinding stage) were in main plots and various application doses (control, 100, 200, 300, $400 \mathrm{ppm}$ ) in subplots. Grain yield and important yield components were highest at late gibberellic acid application time. 0 (control) ppm application doses caused highest grain yield, biological yield and important yield componets. According to the results, late $\mathrm{GA}_{3}$ application positively affected to grain yield. Increasing $\mathrm{GA}_{3}$ application doses had no possitive effect on grain yield. However, hormone applications are not the only determinants of production. Environmental factors and growing techniques are also very effective on yield.
\end{abstract}

Keywords: Cicer arietinum $L_{\text {., }} G A_{3}$, growth regulators, yield, yield components

\section{Introduction}

Chickpea (Cicer arietinum L.) is the second most important pulse crop in the world after dry bean. As well as being an important source of human food and animal feed, it also helps to improve soil fertility, particularly in drylands (Yucel et al., 2006) by fixing atmospheric nitrogen $(\mathrm{N})$. It is mainly used for human consumption and is an essential constituent of the Mediterranean diet and a basic food in Pakistan and India (Millan et al., 2017). The chickpea grain international market is very active due to the crop's nutritional value. Chickpea is a good and cheap source of protein for people in developing countries (especially in South Asia), who are largely vegetarian, either by choice or due to economic reasons (Gaur et al., 2012). Chickpea is high in protein, low in fat and sodium, cholesterol free and is an excellent source of both soluble and insoluble fiber, as well as complex carbohydrates, vitamins, folate, and minerals, especially calcium, phosphorous, iron, and magnesium (Roy et al., 2010). Chickpea has gained great popularity and importance especially in developing countries, and is also being accepted by the developed world now (Jukanti et al., 2012). Chickpea is the most important pulse crop of Turkey grown on 517785 ha and with 630000 tons of production potential (FAO, 2019).

Growth regulators play an essential role in the biosynthesis of crop fibres, affecting both the elongation rate and quality. The gibberellins (GA) are natural plant growth 
promoting hormones that cause the elongation of plant cells. Exogenous application of GA alters plant growth and affects developmental features (Ullah et al., 2017). Treatment efficiency relies on its timing, concentration of $\mathrm{GA}_{3}$ solution and weather conditions following the application (Kaplan, 2011). But no explicit guidelines as to rates and the number of applications of these compounds have been provided (Perez and Gomez, 2000; Casonova et al., 2009; Formolo et al., 2010). The exogenous application of $\mathrm{GA}_{3}$ was observed to enhance the source and sink potential, and further increased dry matter accumulation. The influence of $\mathrm{GA}_{3}$ on plant source strength is through the increased mineral nutrient uptake of the plant and, consequently, the enhanced photosynthetic potential of leaves (Eid and Abou-Leila, 2006).

Gibberellins are a large family of plant hormones which are bioactive growth regulators, controlling seed germination, stem elongation, flowering, pod setting and pod size. For this reason, gibberellic acid was applied in different application time in our research. Among the gibberellins the most predominant is gibberellic acid (gibberellin $\mathrm{A}_{3}$ or $\mathrm{GA}_{3}$ ), because of its frequent and high-level occurrence in microbial fermentations as well as its high biological activity in plants (Bruckner and Blechschmidt, 1991). Gibberellins are one of the growth regulators and they are increase plant growth. They are generally used to provide better growth in flowering and fruit. Giberellin was isolated for the first time in Japan from Gibberella fujikuroi fungi and it was noticed that this fungus caused excessive height elongation in the rice (Secer, 1989). Gibberellic acid is an important growth promoter in plants, and the worldwide demand for it is steadily increasing. The rice pathogen Gibberella fujikuroi is able to produce $\mathrm{GA}_{3}$ and pigments (Kumar and Lonsane, 1988; Chavez-Parga et al., 2008).

The objective of this project was to evaluate different gibberellic acid application time and application doses on yield and yield components on chickpea.

\section{Material and methods}

The field experiment was conducted during the 2013 and 2014 under dryland conditions at the experimental area of the Faculty of Agriculture, Eskisehir Osmangazi University, Eskisehir, Turkey (39 $48^{\prime}$ N; 30 31' E, $798 \mathrm{~m}$ above sea level). Climatic data for long term and experimental years are shown in Figure 1. Long term annual total precipitation is $174.8 \mathrm{~mm}$ and it was 122.9 and $170.6 \mathrm{~mm}$ in the experimental years, respectively. While the average temperature was $15.46^{\circ} \mathrm{C}$ for long term; annual average temperature was $16.68{ }^{\circ} \mathrm{C}$ in 2013 and $16.20^{\circ} \mathrm{C}$ in 2014 . Physical and chemical proporties of the soil at the experimental areas are presented Table 1.

The field experiment was arranged in split plots on randomised complete block design with four replications. Application time (2-3 leaves stages, pre-flowering stage and podbinding stage) were in main plots and application doses [0 (control), 100, 200, 300, 400 ppm] were sub-plots. Chickpea varieties Gokce was used research material. Sowing was made $30 \mathrm{~cm}$ row spacing at a seeding rate of 60 seeds $\mathrm{m}^{-2}$ on 29 April and 26 March in 2013 and 2014, respectively and the basal fertilizer application of $140 \mathrm{~kg} \mathrm{ha}^{-1} \mathrm{DAP}$ (Di-amonium phosphate $(18 \% \mathrm{~N}$ and $46 \% \mathrm{P})$ ] was given to each plot at the sowing. $\mathrm{GA}_{3}$ applications were applied in the 2-3 leaves stage (30 May in 2013 and 17 May in 2014), the pre-flowering stage (8 June in 2013 and 30 May in 2014) and the pod-binding stage (4 July in 2013 and 21 June in 2014). 0 (control), 100, 200, 300 and 400 ppm GA 3 doses were applied in the experiment and only pure water was sprayed on the control plots during the application stages. Flowering time was when $50 \%$ of sub-plots are in 
flowering; harvest maturity time was observed when $90 \%$ of the sub-plots are mature. Harvest time of chickpea was on 30 July 2013 and 21 July 2014 in the first and second year, respectively. Plant height $(\mathrm{cm})$, first pod height $(\mathrm{cm})$, the biological yield per plant $(\mathrm{g})$, pod number per plant, seed number per plant, and grain yield per plant $(\mathrm{g})$ were evaluated on 10 randomly selected plants in each sub-plot. Biological yield $\left(\mathrm{kg} \mathrm{ha}^{-1}\right)$ and harvest index $(\%)$ were estimated from a $0.25 \mathrm{~m}^{-2}$ area. Each sub-plot was harvested, seed yield $\left(\mathrm{kg} \mathrm{ha}^{-1}\right)$ and hundred kernel weight $(\mathrm{g})$ was estimated. Samples were taken from each sub-plots and grain protein content was found by microkjeldahl method (Jones, 1981).
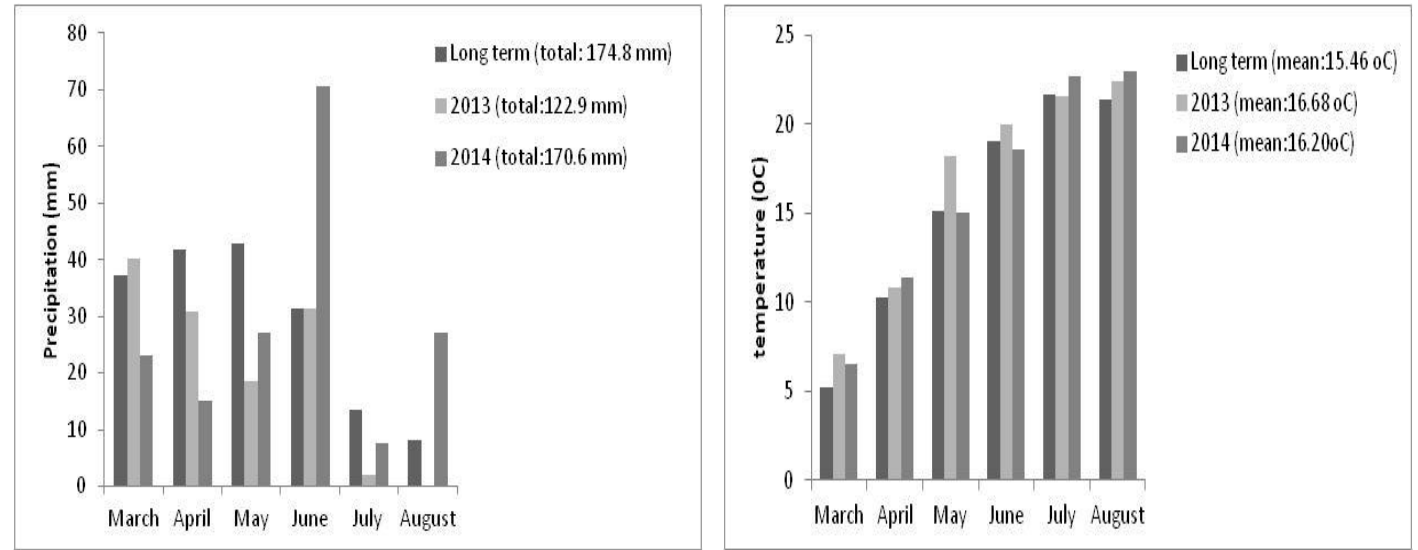

Figure 1. Climatic data of the research area

Table 1. Soil physical and chemical proporties of the experimental area

\begin{tabular}{c|c|c|c|c|c|c|c|c}
\hline Year & $\begin{array}{c}\text { Depth } \\
(\mathbf{c m})\end{array}$ & Texture & $\mathbf{p H}$ & $\begin{array}{c}\text { Total salt } \\
(\boldsymbol{\%})\end{array}$ & $\begin{array}{c}\text { Lime } \\
(\boldsymbol{\%})\end{array}$ & $\begin{array}{c}\text { Organic } \\
\text { matter (\%) }\end{array}$ & $\begin{array}{c}\mathbf{P}_{2} \mathbf{O}_{5} \\
\left(\mathbf{k g ~ h a}^{-1}\right)\end{array}$ & $\begin{array}{c}\mathbf{K}_{2} \mathbf{O} \\
\left(\mathbf{k g ~ h a}^{-1}\right)\end{array}$ \\
\hline $\mathbf{2 0 1 3}$ & $0-30$ & $\begin{array}{l}\text { clayey- } \\
\text { loamy }\end{array}$ & 7.83 & 0.07 & 4.91 & 1.13 & 34.2 & 2150 \\
$\mathbf{2 0 1 4}$ & $0-30$ & loamy & 7.82 & 0.02 & 6.62 & 2.41 & 54.9 & 2090 \\
\hline
\end{tabular}

All data were subjected to analysis of variance based on General Linear Model using the Statview package (SAS Institute). Means were compered by Least Significant Differences (LSD) test.

\section{Results and discussion}

According to analysis of varience, there were significantly differences between year and application doses for flowering time (Table 2). There was a drought on first experimental year especially in May and mean temperatures of May higher than long term (Figure 1). Low precipitation and high temperature may be caused earlier flowering. Bicer and Anlarsal (2004) and Uzun et al. (2012) reported that environmental conditions were affected flowering on chickpea and flowering was be earlier on arid conditions. The highest flowering time was observed on $200 \mathrm{ppm}$ application doses and the lowest value was observed on $0 \mathrm{ppm}$ (control). All of the application doses except to $200 \mathrm{ppm}$ were within same statistically group. High gibberelic acid doses were not effected flowering 
time. Hamano et al. (2002) reported that gibberelic acid applications were not effected flowering time on cabbage varieties. Erdemli (2015) noticed that the flowering was earlier on sunflower when gibberelic acid was application.

Table 2. Effects of different gibberellic acid doses and application times on some traits of chickpea

\begin{tabular}{c|c|c|c|c|c|c|c}
\hline Treatments & $\begin{array}{c}\text { FT } \\
(\mathbf{d a y})\end{array}$ & $\begin{array}{c}\text { PH } \\
(\mathbf{c m})\end{array}$ & $\begin{array}{c}\text { FPH } \\
(\mathbf{c m})\end{array}$ & $\begin{array}{c}\text { HMT } \\
(\mathbf{d a y})\end{array}$ & $\begin{array}{c}\text { BYP } \\
(\mathbf{g})\end{array}$ & PNP & SNP \\
\hline 2013 & $44.15 \mathrm{~B}$ & $31.32 \mathrm{~B}$ & $17.33 \mathrm{~b}$ & $88.65 \mathrm{~B}$ & $7.59 \mathrm{~A}$ & $16.34 \mathrm{~A}$ & $15.83 \mathrm{~A}$ \\
2014 & $63.05 \mathrm{~A}$ & $35.92 \mathrm{~A}$ & $22.38 \mathrm{a}$ & $113.13 \mathrm{~A}$ & $6.05 \mathrm{~B}$ & $8.32 \mathrm{~B}$ & $6.64 \mathrm{~B}$ \\
Mean & 53.60 & 33.62 & 19.85 & 100.89 & $\mathbf{6 . 8 2}$ & $\mathbf{1 2 . 3 3}$ & $\mathbf{1 1 . 2 3}$ \\
2-3 leaves stage & 53.70 & $34.45 \mathrm{~A}$ & $21.36 \mathrm{~A}$ & 100.77 & 6.60 & $11.77 \mathrm{~B}$ & $10.46 \mathrm{C}$ \\
Pre-flowering stage & 53.07 & $35.23 \mathrm{~A}$ & $20.40 \mathrm{AB}$ & 101.42 & 6.89 & $12.14 \mathrm{~B}$ & $11.05 \mathrm{~B}$ \\
Pod-pinding stage & 54.02 & $31.18 \mathrm{~B}$ & $17.80 \mathrm{~B}$ & 100.47 & 6.97 & $13.07 \mathrm{~A}$ & $12.18 \mathrm{~A}$ \\
Mean & 53.60 & 33.62 & 19.85 & 100.89 & $\mathbf{6 . 8 2}$ & $\mathbf{1 2 . 3 3}$ & $\mathbf{1 1 . 2 3}$ \\
Control & $53.03 \mathrm{~b}$ & 32.51 & $18.74 \mathrm{~b}$ & 100.70 & $7.02 \mathrm{~A}$ & $13.14 \mathrm{~A}$ & $12.30 \mathrm{~A}$ \\
100 ppm & $53.41 \mathrm{~b}$ & 33.68 & $19.53 \mathrm{ab}$ & 100.75 & $6.99 \mathrm{~A}$ & $12.50 \mathrm{~B}$ & $11.38 \mathrm{~B}$ \\
200ppm & $54.62 \mathrm{a}$ & 33.06 & $19.12 \mathrm{~b}$ & 101.08 & $7.09 \mathrm{~A}$ & $12.85 \mathrm{AB}$ & $11.50 \mathrm{~B}$ \\
300 ppm & $53.37 \mathrm{~b}$ & 34.66 & $21.08 \mathrm{a}$ & 100.87 & $6.38 \mathrm{~B}$ & $11.48 \mathrm{C}$ & $10.54 \mathrm{C}$ \\
400 ppm & $53.50 \mathrm{~b}$ & 34.20 & $20.82 \mathrm{a}$ & 101.04 & $6.62 \mathrm{AB}$ & $11.67 \mathrm{C}$ & $10.44 \mathrm{C}$ \\
Mean & 53.60 & 33.62 & 19.85 & 100.89 & $\mathbf{6 . 8 2}$ & $\mathbf{1 2 . 3 3}$ & $\mathbf{1 1 . 2 3}$ \\
Year & $* *$ & $* *$ & $*$ & $* *$ & $* *$ & $* *$ & $* *$ \\
Application time & $\mathrm{ns}$ & $* *$ & $* *$ & $\mathrm{~ns}$ & $\mathrm{~ns}$ & $* *$ & $* *$ \\
Application doses & $*$ & $\mathrm{~ns}$ & $*$ & $\mathrm{~ns}$ & $* *$ & $* *$ & $* *$ \\
Year x app. time & $\mathrm{ns}$ & $\mathrm{ns}$ & $\mathrm{ns}$ & $\mathrm{ns}$ & $* *$ & $* *$ & $* *$ \\
Year x app. doses & $\mathrm{ns}$ & $\mathrm{ns}$ & $\mathrm{ns}$ & $\mathrm{ns}$ & $* *$. & $* *$ & $* *$ \\
App. time x app. doses & $\mathrm{ns}$ & $* *$ & $* *$ & $\mathrm{~ns}$ & $* *$ & $* *$ & $* *$ \\
Year x app. time.x app. dos. & $\mathrm{ns}$ & $\mathrm{ns}$ & $\mathrm{ns}$ & $*$ & $* *$ & $* *$ & $* *$ \\
\hline
\end{tabular}

ns: non-significant, $*: \mathrm{p} \leq 0.05, * *: \mathrm{p} \leq 0.01$. Means in the same column with different letters are significant. FT: flowering time PH: plant height FPH: first pod height HMT: harvest maturity time BYP: biological yield per plant PNP: pod number per plant SNP: seed number per plant

There were significantly differences between year and application time for plant height but between year, application time and application doses were significant for first pod height (Table 2). Plant height and first pod height were higher than expected on second experimental year. Higher precipitation on especially June may have been caused higher plant height and first pod height on second experimental year. Highest plant height and first pod height were obtained pre-flowering stage and 2-3 leaves stage, respectively but lowest plant height and first pod height were obtained pod-finding stages. Iqbal et al. (2001) reported that the highest plant height was obtained $20 \mathrm{mg} / \mathrm{L} \mathrm{GA} 3$ doses during flowering time on chickpea. Rahman et al. (2004) stated that they were obtained highest plant height when $\mathrm{GA}_{3}$ applied 45 days after sowing on soybean. While the highest first pod height was obtained $300 \mathrm{ppm}$ application doses, $400 \mathrm{ppm}$ and $300 \mathrm{ppm}$ application doses were being same statistically group. Sanli and Kaya (2008) stated that gibberelic acid applications were increased first pod height on chickpea. While plant height and first pod height showed superior performence 300 and 400 application doses on 2-3 leaves gibberellic acid application but all of the application doses showed better performence on 
2-3 leaves gibberellic acid application. Hence, the interaction between application time $\mathrm{x}$ application doses were significant for plant height and first pod height (Figure 2a,b).
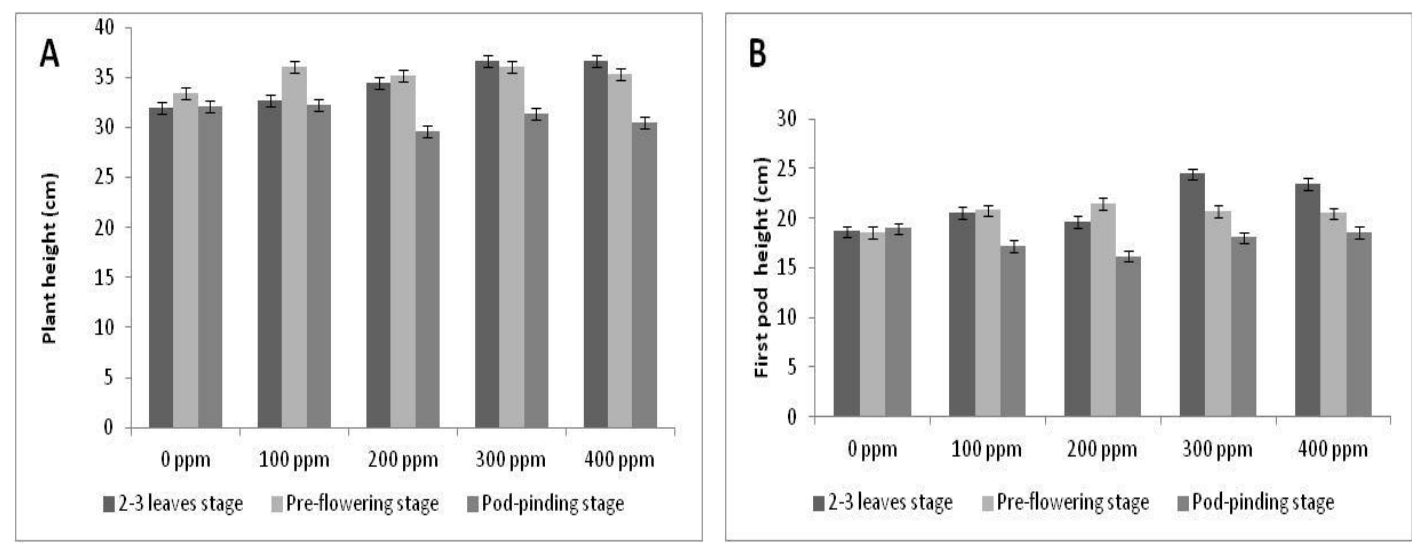

Figure 2. The interaction between giberellic acid doses and application time on plant height (A) and first pod height (B) of chickpea [LSD 1\%: $3.537(A) ; 1 \%: 3.637(B)]$

There were significantly differences between year for harvest maturity time but between application time and application doses were not significant (Table 2). Higher precipitation on esspecially June might be caused longer harvest maturity time on second experimental year. Bicer and Anlarsal (2004) reported that chickpea is reached earlier to harvest maturity time on drought conditions and when the precipitation is so much, harvest maturity time is longer. While harvest maturity time had the highest value on second year, it had the low value on first year. This difference was responsible for year $\mathrm{x}$ application time $\mathrm{x}$ application doses interactions (Figure $3 a$ ).
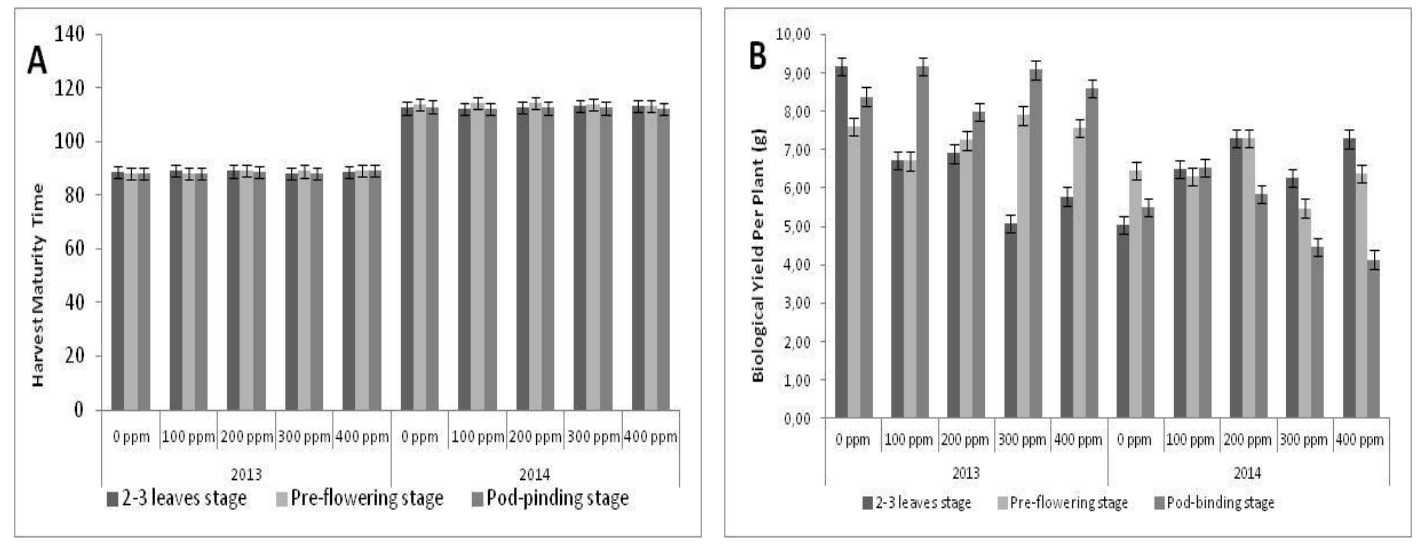

Figure 3. The interaction between giberellic acid doses and application time on Harvest maturity time (A) and biological yield per plant (B) of chickpea [LSD 5\%: $1.060(A) ; 1 \%$ : $1.274(B)]$

Biological yield per plant, pod number per plant, seed number per plant and grain yield per plant were significantly affected by years (Tables 2,3). These values were lower in both years than expected. Experiment of in first year was effectived the drought during to growing season. Experiment of second year precipitation was higher than long term 
but plants were exposed to drought in first development stages (March, April and May). Therefore, these values were lower than expected.

Table 3. Effects of different gibberellic acid doses and application times on some traits of chickpea

\begin{tabular}{c|c|c|c|c|c|c}
\hline Treatments & GYP $(\mathbf{g})$ & $\begin{array}{c}\text { HI } \\
(\mathbf{\%})\end{array}$ & $\begin{array}{c}\text { HKW } \\
(\mathbf{g})\end{array}$ & $\begin{array}{c}\mathbf{G P C} \\
(\mathbf{\%})\end{array}$ & $\begin{array}{c}\mathbf{B Y} \\
\mathbf{( k g ~ h a}^{-\mathbf{1}} \mathbf{)}\end{array}$ & $\begin{array}{c}\mathbf{G Y} \\
\mathbf{( k g ~ h a}^{-\mathbf{1}} \mathbf{)}\end{array}$ \\
\hline 2013 & $3.92 \mathrm{~A}$ & $47.25 \mathrm{~A}$ & $36.72 \mathrm{~b}$ & 21.06 & $3534.91 \mathrm{~A}$ & $556.02 \mathrm{~A}$ \\
2014 & $2.59 \mathrm{~B}$ & $31.80 \mathrm{~B}$ & $38.73 \mathrm{a}$ & 21.52 & $2575.93 \mathrm{~B}$ & $488.13 \mathrm{~B}$ \\
Mean & $\mathbf{3 . 2 5}$ & $\mathbf{3 9 . 5 2}$ & 37.72 & 21.29 & $\mathbf{3 0 5 5 . 4 2}$ & $\mathbf{5 2 2 . 0 7}$ \\
2-3 leaves stage & $3.10 \mathrm{~B}$ & $40.92 \mathrm{~A}$ & 37.36 & 21.17 & $3408.10 \mathrm{~A}$ & $497.06 \mathrm{~B}$ \\
Pre-flowering stage & $3.24 \mathrm{~B}$ & $37.73 \mathrm{~B}$ & 37.97 & 21.65 & $3130.17 \mathrm{~B}$ & $583.58 \mathrm{~A}$ \\
Pod-binding stage & $3.42 \mathrm{~A}$ & $39.93 \mathrm{~A}$ & 37.83 & 21.06 & $2628.00 \mathrm{C}$ & $485.59 \mathrm{~B}$ \\
Mean & $\mathbf{3 . 2 5}$ & $\mathbf{3 9 . 5 2}$ & 37.72 & 21.29 & $\mathbf{3 0 5 5 . 4 2}$ & $\mathbf{5 2 2 . 0 7}$ \\
Control & $3.45 \mathrm{~A}$ & $40.43 \mathrm{AB}$ & 37.16 & 21.31 & $3457.67 \mathrm{~A}$ & $562.59 \mathrm{~A}$ \\
100 ppm & $3.42 \mathrm{~A}$ & $41.31 \mathrm{~A}$ & 37.78 & 21.24 & $2804.83 \mathrm{C}$ & $536.03 \mathrm{~A}$ \\
200ppm & $3.44 \mathrm{~A}$ & $40.04 \mathrm{~B}$ & 37.96 & 21.40 & $2935.50 \mathrm{C}$ & $544.15 \mathrm{~A}$ \\
300 ppm & $3.00 \mathrm{~B}$ & $38.56 \mathrm{C}$ & 38.10 & 21.45 & $3223.11 \mathrm{~B}$ & $508.01 \mathrm{~B}$ \\
400 ppm & $2.96 \mathrm{~B}$ & $37.30 \mathrm{D}$ & 37.62 & 21.05 & $2856.00 \mathrm{C}$ & $459.60 \mathrm{C}$ \\
Mean & $\mathbf{3 . 2 5}$ & $\mathbf{3 9 . 5 2}$ & 37.72 & 21.29 & $\mathbf{3 0 5 5 . 4 2}$ & $\mathbf{5 2 2 . 0 7}$ \\
Year & $* *$ & $* *$ & $*$ & $\mathrm{~ns}$ & $* *$ & $* *$ \\
Application time & $* *$ & $* *$ & $\mathrm{~ns}$ & $\mathrm{~ns}$ & $* *$ & $* *$ \\
Application doses & $* *$ & $* *$ & $\mathrm{~ns}$ & $\mathrm{~ns}$ & $* *$ & $* *$ \\
Year x app. time & $* *$ & $* *$ & $\mathrm{~ns}$ & $\mathrm{~ns}$ & $* *$ & $* *$ \\
Year x app. doses & $* *$ & $\mathrm{~ns}$ & $\mathrm{~ns}$ & $\mathrm{~ns}$ & $* *$ & $* *$ \\
App. time x app. doses & $* *$ & $* *$ & $\mathrm{~ns}$ & $\mathrm{~ns}$ & $* *$ & $* *$ \\
Year x app. time.x app. dos. & $* *$ & $* *$ & $\mathrm{~ns}$ & $\mathrm{~ns}$ & $* *$ & $* *$ \\
\hline
\end{tabular}

ns: non-significant, ${ }^{*}: \mathrm{p} \leq 0.05,{ }^{* *}: \mathrm{p} \leq 0.01$. Means in the same column with different letters are significant. GYP: grain yield per plant HI: harvest index HKW: hundred kernel weight GPC: grain protein content BY: biological yield GY: grain yield

Biological yield per plant, pod number per plant, seed number per plant and grain yield per plant are higher in the first year than second year. Total precipitation in second year is higher than first year but plants were affected by drought in March, April and May in second year. This drought may have been caused lower values of these yield components (Figure 1). Pod number per plant, seed number per plant and seed yield per plant, gibberellic acid application applied at pod binding stages are higher than other application times. Rahman et al. (2004) said that the highest pod per plant and grain yield per plant were obtained late gibberellic acid application. Sarihan (2004) is reported that the highest capsule number per plant is obtained by late application of gibberellic acid on poppy. The highest biological yield per plant, pod number per plant, seed number per plant and grain yield per plant were obtained $0 \mathrm{ppm}$ (control) application dose. Gibberellic acid application doses did not increase the yield components. While the all of the yield componets had the highest value in first year, they had the low value in second year. This difference was responsible for year $\mathrm{x}$ application time $\mathrm{x}$ application doses interactions (Figures 3b, 4ab, 5a). 

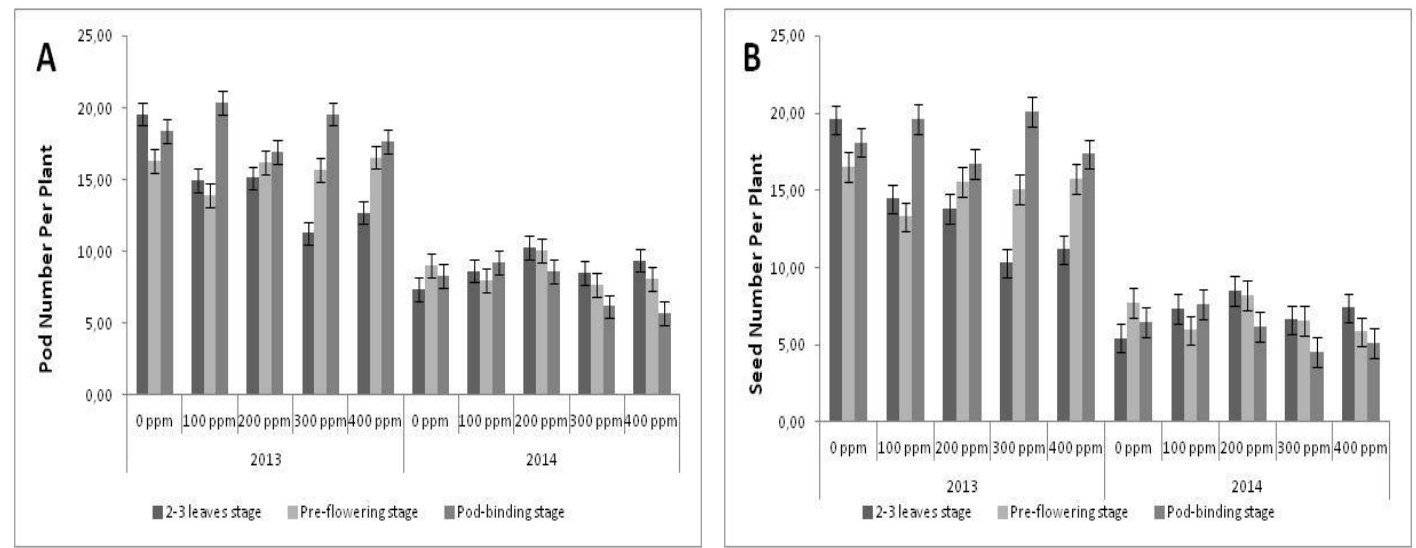

Figure 4. The interaction between giberellic acid doses and application time on pod number per plant (A) and seed number per plant (B) of chickpea [LSD 1\%: 1.188 (A); 1.122(B)]
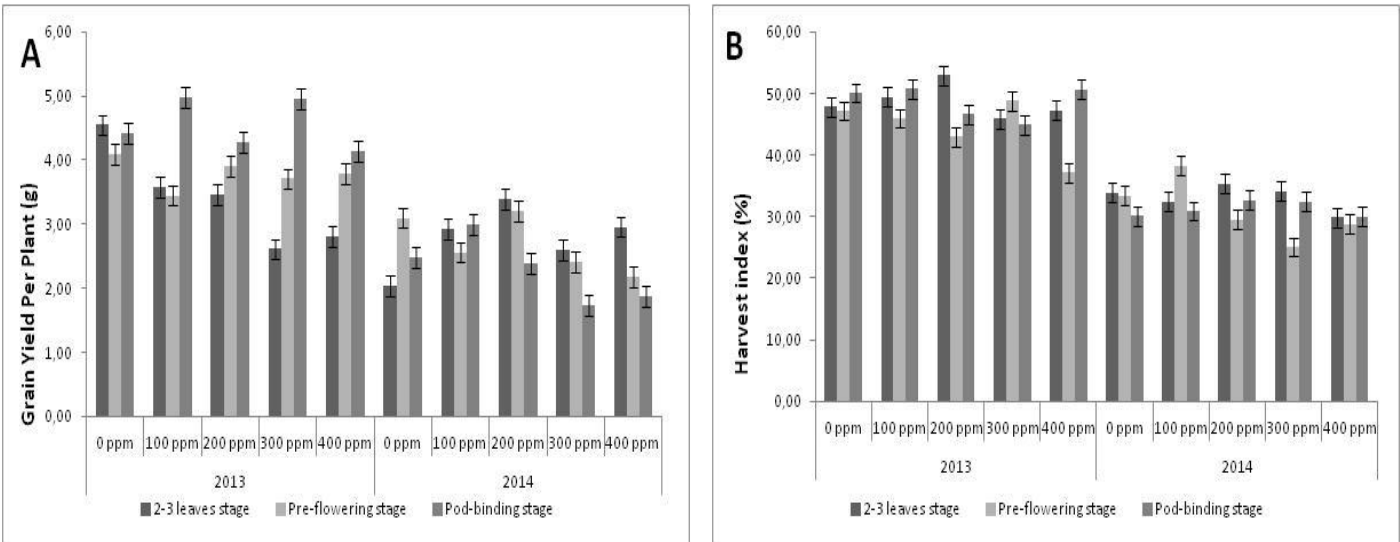

Figure 5. The interaction between giberellic acid doses and application time on grain yield per plant (A) and harvest index (B) of chickpea [LSD 1\%: 0.551 (A); 2.720(B)]

Harvest index was significantly affected by years (Table 3) and it is higher in the first year than second year. The drought occurred in first experimental year and drought caused lower biological yield. Therefore, the harvest index is higher in first experimental year (Figure 1). Harvest index was higher in 2-3 leaves gibberellic acid application but 2-3 leaves gibberellic acid application values and pod-binding values were in same statistically group for harvest index. The highest harvest index was obtained $100 \mathrm{ppm}$ application doses. Hoque and Hoque (2002) reported that gibberellic acid application was increased harvest index and they obtained highest harvest index in $200 \mathrm{ppm}$ gibberellic acid doses. While harvest index had the highest value in first year, it had the low value in second year. This difference was responsible for year $\mathrm{x}$ application time $\mathrm{x}$ application doses interactions (Figure $5 b$ ).

There were significantly differences between year for hundred kernel weight but between application time and application doses were not significant (Table 2). Ekberli and Kars (2020) reported that environmental, climatic and soil factors may be effective on hundred kernel weight.

Biological yield was significantly affected by years (Table 3). Biological yield was lower in both years than expected. Experiment of in first year was effectived the drought 
during to growing season. Therefore, lower biological yield was obtained than expected on first year. Precipitation was higher than long term on second year but plants were exposed to drought in first development stages. Therefore, biological yield was lower than expected. Biological yield is higher in the first year than second year. Total precipitation in second year is higher than first year but plants were affected by drought in March, April and May in second year and this drought may have been caused lower biological yield (Figure 1). The highest biological yield was obtained in 2-3 leaves gibberellic acid application. Early gibberellic acid application time was increased biological yield. 0 (control) ppm application doses caused highest biological yield. The $300 \mathrm{ppm}$ application doses showed superior performence under 2-3 leaves gibberellic acid application in the 2013 but same application doses performed better performence under pod-binding gibberellic acid application stage in 2014. Hence, the interaction between year, application time and application doses were significant for biological yield (Figure 6a).
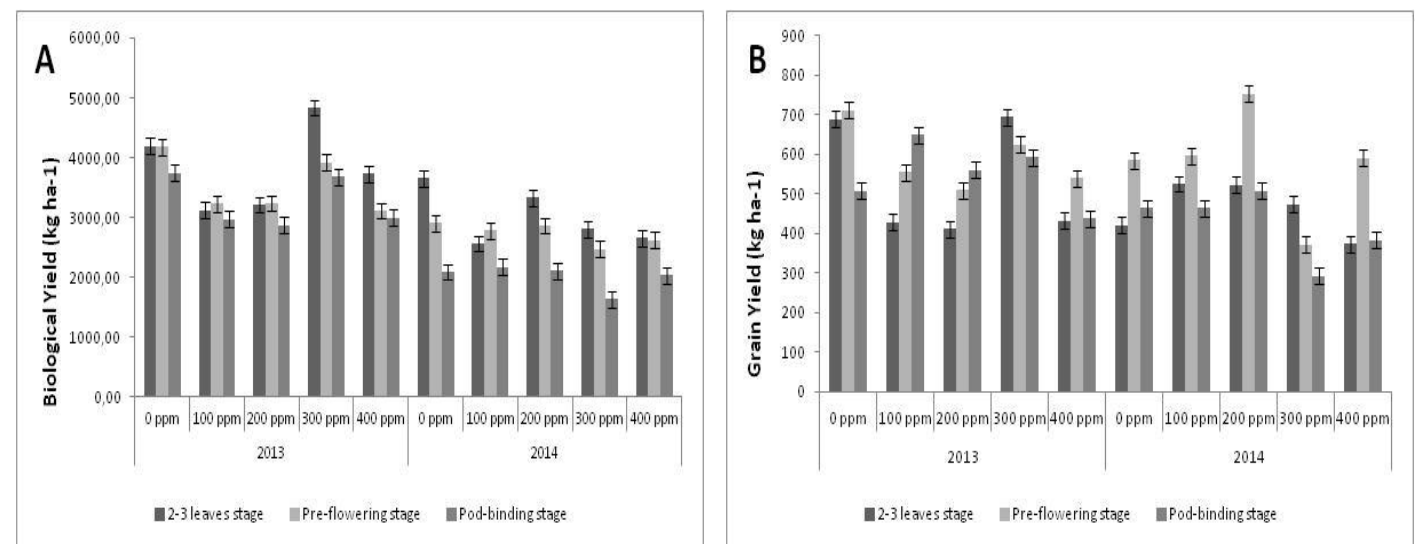

Figure 6. The interaction between giberellic acid doses and application time on biological yield (A) and grain yield (B) of chickpea [LSD 1\%: $42.282(A) ; 6.760(B)]$

Grain yield was significantly affected by years (Table 3). Grain yield was lower in both years than expected. Experiment of in first year was effectived the drought during to growing season and grain yield was lower than expected. Precipitation was higher than long term on second year but plants were exposed to drought in first development stage. Furthermore, there was very high rainfall in June in second year. High precipitation during the flowering period (in June) might be negatively affected the pollination. Therefore, grain yield was lower than expected. Grain yield is higher in the first year than second year. Total precipitation in second year is higher than first year but high precipitation during the flowering period might be caused lower grain yield (Figure 1). The highest grain yield was obtained in pre-flowering gibberellic acid application stages. Late gibberellic acid application time was increased grain yield. Rahman et al. (2004) reported that late stage $\mathrm{GA}_{3}$ application was increased grain yield in soybean plants. Niknejhad and Pirdashti (2012) said that pre-flowering $\mathrm{GA}_{3}$ application was increased grain yield in rice. 0 (control) ppm application doses caused highest grain yield. Baydar (2000) reported that $\mathrm{GA}_{3}$ application was significantly reduced grain yields in safflower. Kaya et al. (2010) said that increasing $\mathrm{GA}_{3}$ doses were negative affected to grain yield in chickpea. The $300 \mathrm{ppm}$ application doses showed superior performence under 2-3 leaves stage in the 2013 but same application doses performed better performence under pod- 
binding stage in 2014. Hence, the interaction between year, application time and application doses were significant for grain yield (Figure $6 b$ ).

\section{Conclusion}

All of the characteristics were significantly affected by years. Experiment of in first year was effectived the drought during to growing season. Precipitation was higher than long term on second year but plants were exposed to drought in first development stages and high precipitation during the flowering period (in June) was negatively affected the pollination. Grain yield and important yield components were highest in late gibberellic acid application time. Late gibberrellic acid application time was possitive affected grain yield and yield components. Late application of gibberellic acid will be more effective. 0 (control) ppm application doses caused highest grain yield, biological yield and important yield componets. According to the results, late $\mathrm{GA}_{3}$ application was possitive affected to grain yield but increasing gibberellic acid doses were not positively affected to grain yield. However, hormone applications are not the only determinants of production. Environmental factors and growing techniques are also very effective on yield.

Acknowledgements. This article was extracted from the M.Sc. thesis of Ergin, N.

\section{REFERENCES}

[1] Baydar, H. (2000): Effects of gibberellic acid on male sterelity, seed yield and oil and fatty acids syntheses of safflower (Carthamus tinctorius L.). - Turkish Journal of Biology 24: $159-168$.

[2] Bicer, B. T., Anlarsal, A. E. (2004): Determination of botanical and agronomical characteristics of some chickpea (Cicer arietinum L.) landraces. - Journal of Agricultural Sciences 10(4): 389-396.

[3] Bruckner, B., Blechschmidt, D. (1991): The gibberellins fermentation. - Critical Rev Biotehnology 11(2): 163-192.

[4] Casanova, L., Casanova, R., Moret, A., Agusti, M. (2009): The application of gibberellic acid increases berry size of 'Emperatiz' seedless grape. - Spanish Journal of Agricultural Research 7: 919-927.

[5] Chavez-Parga, M. C., Gonzoles-Ortaga, O., Negrete-Rodriguez, M. L. X., Vallarino, G., Alatorre, G. G., Escamilla-Silvia, E. M. (2008): Kinetics of the gibberellic acid and bikaverin product in an airlift bioreactor. - Process Biochem 43(8): 855-860.

[6] Eid, R. A., Abou-Leila, B. H. (2006): Response of croton plants to gibberellic acid benzyl adenine and ascorbic acid application. - World Journal of Agricultural Science 2: 174179.

[7] Ekberli, İ., Kars, N. (2020): Creation of Liner Regression Models Between Yield Parameters of Soybean Plant and Some Physical and Chemical Properties of Soil. Anadolu Journal of Agricultural Sciences 35: 77-87.

[8] Erdemli, H. (2015): The effects of gibberellic acid doses on yield and germination under abiotic stress conditions in sunflower (Helianthus annuus L.). - Eskisehir Osmangazi University, Institute of Science, Graduate Thesis, Eskisehir.

[9] FAO (2019): http://faostat3.fao.org/browse/Q/QC/E. - Accessed to web: 12.04.2021.

[10] Formolo, R., Rufato, L., Kretzschmar, A. A., Schlemper, C., Mendes, M., Marcon Filho, J. L., Lima, A. P. (2010): Gibberellic acid and cluster thinning on seedless grape 'BRS 
Clara' in caxias do sul, Rio Grande do Sul State, Brazil. - Acta Horticulturae 884: 467471.

[11] Gaur, P. M., Jukanti, A. K., Varshney, R. K. (2012): Impact of genomic technologies on chickpea breeding strategies. - Agronomy 2: 199-221.

[12] Hamano, M., Yamato, Y., Amazaki, H., Miura, H. (2002): Endogenous gibberellins and their effects on flowering and stem elongation in cabbage (Brassica oleracea var. capitata). - The Journal of Horticultural Science and Biotechology 77: 220-225.

[13] Iqbal, H. F., Tahir, A., Khalid, M. N., Ul-Haq, I., Ahmad, A. N. (2001): Response of chickpea (Cicer arietinum L.) growth towards the foliar application of gibberellic acid at different growth stages. - Pakistan Journal of Biological Science 4(4): 433-434.

[14] Jones, D. I. H. (1981): Chemical composition and nutritive value. - In: Handson, J., Baker, R. D., Davies, A., Laidlow, A. S., Leawer, J. D. (eds.) Sward Measurement Handbook. Kenilworth, UK: The British Grassland Society Press, pp. 243-265.

[15] Jukanti, A. K., Gaur, P. M., Gowda, C. L. L., Chibbar, R. N. (2012): Nutritional quality and health benefits of chickpea (Cicer aietinum L.): a review. - British Journal of Nutrition 108: 11-26.

[16] Kapłan, M. (2011): Effect of growth regulator application technique on quality of grapevine 'einset seedless' variety (in polish). - Acta Agrobotanica 64: 189-196.

[17] Kaya, M., Sanli, A., Tonguc, M. (2010): Effect of sowing dates and seed treatments on yield, some yield parametres and protein content of chickpea (Cicer arietinum L.). African Journal of Biotechnology 9(25): 3833-3839.

[18] Kumar, P. K. R., Lonsane, B. K. (1988): Immobilized growing cells of gibberella fujikuroi P-3 for production of gibberellic acid and pigment in batch and semi-continuous cultures. - Applied Microbiology and Biotehnology 28: 537-542.

[19] Millan, T., Winter, P., Jungling, R., Gil, J., Rubio, J., Cho, S., Cobos, M. J., Iruela, M., Rajesh, P. N., Tekeoglu, M., Kahl, G., Muehlbauer, F. J. (2017): A consensus genetic map of chickpea (Cicer arietinum L.) based on 10 mapping populations. - Euphytica 175: 175-189.

[20] Niknejhad, Y., Pirdashti, H. (2012): Effect of growth stimulators on yield and yield components of rice (Oryza sativa L.) ratoon. - International Research Journal of Applied and Basic Sciences 3(7): 1417-1421.

[21] Perez, F. J., Gomez, M. (2000): Possible role of soluble invertase in the gibberellic acid berry-sizing effect in sultana grape. - Plant Growth Regulators 30: 111-116.

[22] Rahman, S., Islam, N., Tahar, A., Karim, A. (2004): Influence of GA3 and MH and their time of spray on morphology, yield contributing characters and yield of soybean. - Asian Journal of Plant Science 3(5): 602-609.

[23] Roy, F., Boye, J. I., Simpson, B. K. (2010): Bioactive proteins and peptides in pulse crops: Pea, chickpea and lentil. - Food Research International 43: 432-442.

[24] Sanli, A., Kaya, M. (2008): Effects of seed treatments and different sowing times on some agronomic characters of chickpea (Cicer arietinum L.). - Suleyman Demirel University Journal of the Faculty of Agriculture 3(2): 42-51.

[25] Sarihan, E. O. (2004): The effects of different doses and application periods of gibberellic acid $\left(\mathrm{GA}_{3}\right)$ on yield and some characteristics of poppy (Papaver somniferum L.). Ankara University, Institute of Science, M.Sc. thesis, Ankara.

[26] SAS Institute (1998): Statistical Analysis System Institute: Stat View Reference Manual. - SAS Institute, Cary, NC.

[27] Secer, M. (1989): Physiological effects of natural growth regulators (plant hormones) on plants and investigations in this area. - Derim 6(3): 109-124.

[28] Ullah, S., Anwar, S., Rehman, M., Khan, S., Zafar, S., Liu, L., Peng, D. (2017): Interactive effect of gibberellic acid and NPK fertilizer combinations on ramie yield and bast fibre quality. - Scientific Reports 7: 10647. DOI:10.1038/s41598-017-09584-5. 
[29] Uzun, A., Ozcelik, H., Yilmaz, S. (2012): Evaluation of some selected chickpea (Cicer arietinum L.) lines in respect to agronomic and quality traits. - Academic Journal of Agricultural Research 1(1): 29-36.

[30] Yucel, D. O., Anlarsal, A. E., Yucel, C. (2006): Genetic variability, correlation and path analysis of yield, and yield components in chickpea (Cicer arietinum L.). - Turkish Journal of Agricultural and Forestry 30: 183-188. 